\title{
Isolation and Identification of Osmophilic Yeasts Isolated from Molasses Sugarcane as Bioethanol Starter
}

\author{
Nurhayati \\ Dept. of agricultural Products Technology \\ Faculty of Agricultural Technology \\ Jember, Indonesia \\ Correspondence author nurhayati.ftp@unej.ac.id \\ Ika Fitriyah \\ Dept.of Biology \\ Faculty of Mathematics and Natural Sciences \\ Jember, Indonesia \\ nhyati04@yahoo.com
}

\author{
Bambang Sugiharto \\ Dept.of Biology \\ Faculty of Mathematics and Natural Sciences \\ Jember, Indonesia \\ sugiharto.fmipa@unej.ac.id \\ Jayus Jayus \\ Dept. of agricultural Products Technology \\ Faculty of Agricultural Technology \\ Jember, Indonesia \\ jayus.ftp@unej.ac.id
}

\begin{abstract}
Osmophilic yeasts was second generation to increase of the bioethanol production. The yeasts were isolated from the high sugar ontain material like honey, juice or byproduct materials such as molasses. Bioethanol was usually produced from sugarcane molasses at brix degree of $14 \%$. The aim of the research Reviews These were isolation and identification of phenotypic identification of indigenous-molasses yeast. A phenotypic characteristics were based on typical colony, morphological and fermentation profile. The yeasts were isolated from original molasses ( $>80 \%$ brix) on malt extract agar (MEA). There were two isolates of osmophilic yeasts. Isolate A regular was clear white colony, sharpe cell with multilateral budding, while isolate $B$ was murky white colony regular, cylindrical cell with multilateral budding. Isolate $A$ and $B$ optimum grown at $30^{\circ} \mathrm{C}$ and produce high ethanol at $34^{\circ} \mathrm{Brix}$ but the $\mathrm{pH}$ of the growth of yeast were difference. Isolate $A$ growth optimum at $\mathrm{pH}$ 5 , while isolate $\mathrm{B}$ optimum growth at $\mathrm{pH} 4$. The fermentation profile using the API 20C Aux kit Showed that the yeasts can Ferment glucose, glycerol, calcium-2-keto-gluconate, arabinose, adonitol, galactose, sorbitol, methyl- $\alpha \mathrm{D}$-glucopiranoside, $\mathrm{N}$ acetyl-glucosamine, Cellobiose, maltose, sacharose, trehalose, and raffinose. Isolate $A$ Ferment can inositol and melezitose, while isolate B can Ferment xylose and xylitol. Isolate A was identified as Candida famata $(63.2 \%)$ and $B$ isolates was identified as Candida guilliermondii (84.3\%).
\end{abstract}

Keywords-bioethanol fermentation, osmophilic yeast, sugarcane

\section{INTRODUCTION}

Molasses used as a medium for the production of commercial alcohol on alcoholic fermentation industry, because it is easily obtained widely, cheaply and as the quality of raw materials [1]. Industry uses a substrate with a sugar concentration is $16-18 \%$, if the sugar concentration is higher than $18 \%$ will cause osmotic pressure which reduces the efficiency of the fermentation process [2].

In the bioethanol industry, the sugar concentration on the substrate used is $16-18 \%$, and if it is higher than $18 \%$ will cause osmotic pressure which reduces the efficiency of the fermentation process, so as to isolate the species or strain of yeast osmofilik origin of molasses that are resistant to high osmotic pressure by characterizing the morphology, physiology and molecular identification. Several studies have isolation of yeast osmofilik of Indonesian food such as honey, milk and fruit jams, obtained yeast isspecies Candidametapsilosis, C. etchelsii, C. parapsilosis, C. orthopsilosis and Sterigmatomyces halophilus [3]

This study aimed to isolate the origin osmofilik molasses yeast, characterize morphology and physiology as well as identify the molecular origin of yeast osmofilik molasses. Yeast osmofilik molasses origin was expected to be applied to the production of bioethanol with high brix sugar cane molasses, or more than $14^{\circ}$. It is hoped that the yeast will have a good adaptability to the production of molasses alcohol with the substrate.

\section{METHODS}

\section{A. Materials}

Molasses was take from PG. Jatiroto sugarcane milling at season 2015. The molasses was preparated by taking a sufficiently concentrated molasses and molasses brix measured $14^{\circ}, 24^{\circ}$ and $34^{\circ}$ using a refractometer. Molasses brix $34^{\circ}$ was made of $200 \mathrm{ml}$ of concentrated molasses and diluted with $350 \mathrm{~mL}$ of distilled water. Molasses brix $24^{\circ}$ was made of $200 \mathrm{ml}$ of concentrated and diluted with $555 \mathrm{~mL}$ of distilled water. Molasses brix $14^{\circ}$ was made of $200 \mathrm{ml}$ of concentrated and diluted with $935 \mathrm{~mL}$ of distilled water.

\section{B. Isolation Yeast}

Isolation of molasses indigenous yeasts was carried out by taking $1 \mathrm{ml}$ of concentrated molasses and spread on a solid MEA media with dispersive method at 2 petridish. Every isolates were grown from each petridish, purified on MEA solid media with a $3 x$ quadrant scratch method. Isolates were purified, scratched back on a slanted MEA media as saving culture and work culture. 


\section{Morphological characterization}

Morphological characterization was done by macroscopic and microscopic observation. Macroscopic observation was conducted by observing the yeast colonies that grow directly on the surface of the MEA media, including colony shape and color of the colony. Microscopic observations done by creating a wet mount. Wet mount was made to fix the yeast cells on a glass object,given thedye, crystal violetand do repainting with a mordant. The final stage, was observed under a microscope magnification of $1000 \mathrm{X}$ with the addition of immersion oil and covered with a coverglass. Microscopic observations made include cell shape, presence cell budding and type of budding cell.

\section{Physiology Characterization}

Physiological characterization of yeast was conducted on the test temperature and $\mathrm{pH}$ growth, endurance test molasses brix grow at $14^{\circ}, 24^{\circ}$ and $34^{\circ}$, and analyse of alcohol production. Profile of fermentation was analyzed by using API 20C-Aux Kit.

\section{1) Test of yeast growth temperatures}

This test was performed by taking $0.03 \mathrm{ml}$ of $3 \mathrm{ml}$ of yeast culture MEB age of 48 hours, then inoculated in $1 \mathrm{ml}$ of sterile MEB media. Each yeast culture was incubated at different temperatures: $10^{\circ} \mathrm{C}, 20^{\circ} \mathrm{C}, 30^{\circ} \mathrm{C}, 40^{\circ} \mathrm{C}$ and $50^{\circ} \mathrm{C}$ for 48 hours. Observations yeast growth at any temperature, was done by measuring the absorbance values of each yeast culture using a spectrophotometer at OD $600 \mathrm{~nm}$ on incubation time of 12 hours, 24 hours, 36 hours and 48 hours.

\section{2) Test of yeast growth $\mathrm{pH}$}

This test was performed by taking $0.03 \mathrm{ml}$ of $3 \mathrm{ml}$ of yeast culture MEB age of 48 hours, then inoculated in $1 \mathrm{ml}$ of sterile MEB medium with a $\mathrm{pH}$ of 3, 4, 5, 6. Each yeast culture was incubated at $30^{\circ} \mathrm{C}$ for 48 hours. Observation of yeast growth on any media $\mathrm{pH} \mathrm{MEB}$, carried out by measuring the absorbance values of each yeast culture using a spectrophotometer at OD $600 \mathrm{~nm}$ on incubation time of 12 hours, 24 hours, 36 hours and 48 hours.

\section{3) Test of yeast growth on molasses at brix $14^{\circ}, 24^{\circ}$ and $34^{\circ}$}

Test was done by taking a $0.03 \mathrm{~mL}$ of work culture of yeast in $3 \mathrm{ml}$ MEB age of 48 hours, then inoculated in $3 \mathrm{ml}$ of sterile molasses brix $14^{\circ}, 24^{\circ}$ and 34 , and incubated at $30^{\circ} \mathrm{C}$ for 24 hours and 48 hours. Growing endurance test was conducted using the scatter. On the control, yeast culture in $3 \mathrm{ml} \mathrm{MEB}$ life of 48 hours, inoculated in $3 \mathrm{ml}$ physiological saline. Furthermore, the yeast culture was taken as $1 \mathrm{ml}$ and diluted in $9 \mathrm{ml}$ physiological saline solution at a dilution series of $10^{-}$ ${ }^{1}$ to $10^{-7}$. Yeast culture (age of 24 hours and 48 hours) was taken as $1 \mathrm{ml}$ and inoculated at $9 \mathrm{ml}$ physiological saline solution and diluted with a series of $10^{-1}$ to $10^{-7}$. Dilution series of $10^{-4}, 10^{-5,} 10^{-6}$ and $10^{-7}$ in the control and treatment groups was taken each of $1 \mathrm{ml}$, plated on solid MEA medium and incubated at $30^{\circ} \mathrm{C}$ for 48 hours. Yeast colonies growing on each plate, count the number of colonies compared to the control (Log CFU / ml).
This test was performed using the API 20C-Aux kit, consisting of 20 wells were wells first as a negative control (O), pitting both as a positive control containing glucose (GLU), and 18 sinks more were glycerol (Gly), calcium 2keto-gluconate (2KG), arabinose (ARA), xylose (XYL), adonitol (ADO), xylitol (XLT), galactose (GAL), inositol (INO), sorbitol (SOR), methyl- $\alpha \mathrm{D}$-glucopyranoside (MDG), $\mathrm{N}$ - acetyl-Glucosamine (NAG), Cellobiose (CEL), lactose (LAC), maltose (MAL), saccharose (SAC), trehalose (TRE), melezitose (MLZ) and raffinose (RAF). Fermentation profile was performed by standard procedures (bioMerieux, 2010). Observations pattern of fermentation after 48 hours and 72 hours was based on whether or not the substrate turbid sugar on pitting. If the media becomes cloudy, it mean a positive reaction and if the media was clear (not cloudy), it mean negative reaction. The results were written on a sheet result, accumulated and acquired on 7 digit biocode. The code was compared with the identification book or dikonfimasi on apiweb $^{\mathrm{TM}}$ (https: //apiweb.biomerieux.com//) to identify the type of yeast.

\section{RESULTS AND DISCUSSION}

\section{A. Morphological Characteristics}

Isolation of osmophilic-molasses indigenous yeasts obtained two isolates that isolates 1 on the first petridish was coded A and isolates 2 on the second petridish was coded B. Purification of isolates was conducted by using quadrant scratch with three times. Single colony was purified again using the scratch method as savings culture and work culture.

Macroscopic characteristics of yeast was based on the appearance of colonies grown on a solid medium, including textures, shapes, colors, margins, elevation and the surface of colony. Microscopic charactertics included cell shape, cell size, formation of budding, sprouting type (budding cell), and the presence or absence pseudohyphae/hyphae [4,5]. Microscopic observations used observation under the microscope Leica DM 2500, 1000x magnification by addition of emersi oil. Macroscopic and microscopic characters of yeast isolates A and B were shown in Table 1.

Microscopic characteristics of isolate A were round cell shape, cell budding with multilateral type. While the microscopic characteristics of isolate B were cylindrical cells, cell budding with multilateral type. Microscopic characteristics of isolate A and B were shown in Figure 1.

Table 1 Morphological characteristics of A and B isolates

\begin{tabular}{|c|c|c|c|c|c|}
\hline \multirow{2}{*}{$\begin{array}{l}\text { Isolates } \\
\text { Yeast }\end{array}$} & \multicolumn{2}{|c|}{$\begin{array}{l}\text { Macroscopic } \\
\text { characteristics }\end{array}$} & \multicolumn{3}{|c|}{ Microscopic characteristics } \\
\hline & $\begin{array}{l}\text { Shape of } \\
\text { colonies }\end{array}$ & $\begin{array}{l}\text { Colonies } \\
\text { color }\end{array}$ & $\begin{array}{l}\text { Cells } \\
\text { form }\end{array}$ & Budding & $\begin{array}{l}\text { budding } \\
\text { type }\end{array}$ \\
\hline $\begin{array}{l}\mathrm{A} \\
\mathrm{B}\end{array}$ & $\begin{array}{l}\text { Bulat } \\
\text { Round }\end{array}$ & $\begin{array}{l}\text { White } \\
\text { white }\end{array}$ & $\begin{array}{c}\text { Bulat } \\
\text { Cylinders }\end{array}$ & $\begin{array}{l}\text { There } \\
\text { there }\end{array}$ & $\begin{array}{l}\text { Multilateral } \\
\text { multilateral }\end{array}$ \\
\hline
\end{tabular}

\section{4) Fermentation Test Pattern}



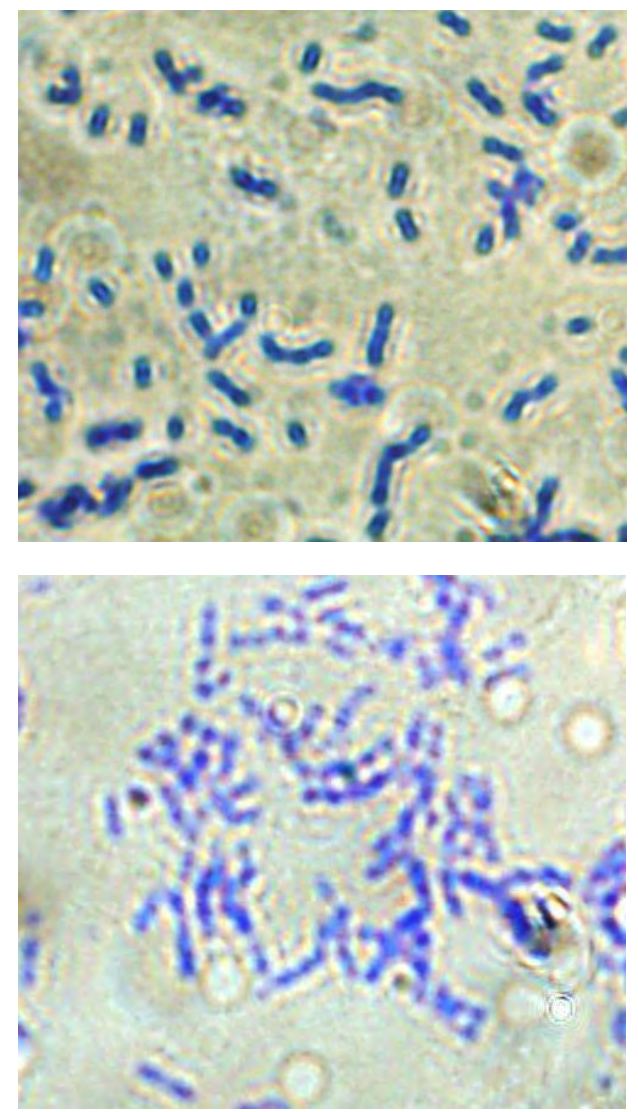

Isolate after $20 \mathrm{~h}$ incubation
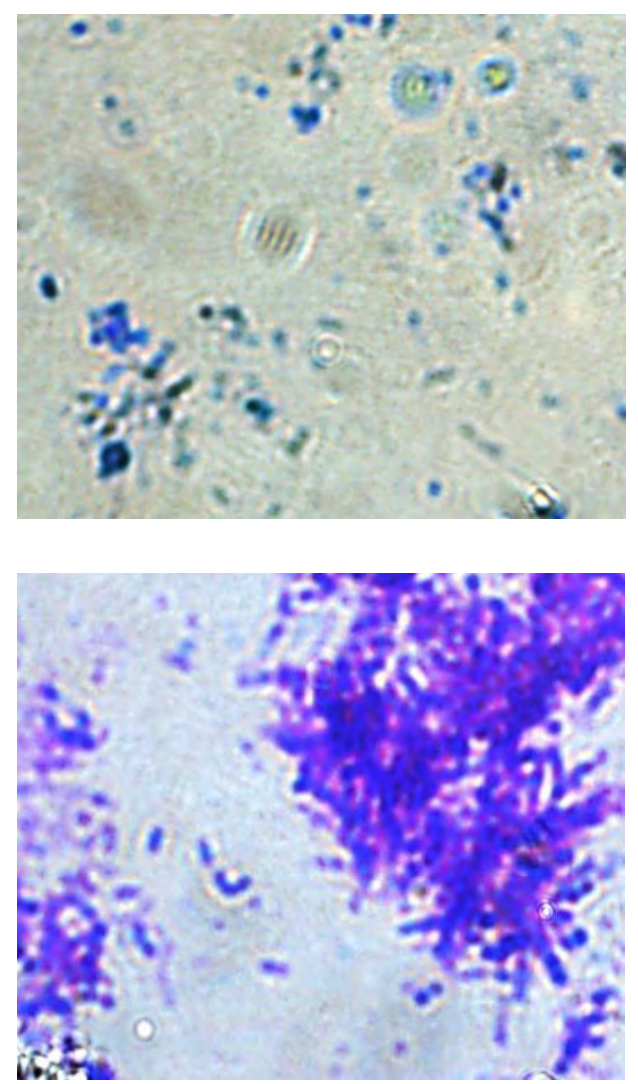

Isolate after $40 \mathrm{~h}$ incubation

Figure 1. Microscopic characteristics of isolate $\mathrm{A}$ and isolate $\mathrm{B}$ after $20 \mathrm{~h}$ and $40 \mathrm{~h}$ incubation at 400x magnification

\section{B. Physiology Characterization}

The isolate A can good growth at $20-30^{\circ} \mathrm{C}$, while the isolate $\mathrm{B}$ can good growth at $30-40^{\circ} \mathrm{C}$, but the both of isolate can optimum growth at $30^{\circ} \mathrm{C}$. Fardiaz [6] reported that the optimum growth at $25-30^{\circ} \mathrm{C}$. Figure 2 and Figure 3 showed the growth of yeasts isolate $\mathrm{A}$ and $\mathrm{B}$ at some growth temperature $\left(20^{\circ} \mathrm{C}, 30^{\circ} \mathrm{C}, 40^{\circ} \mathrm{C}, 50^{\circ} \mathrm{C}\right)$.

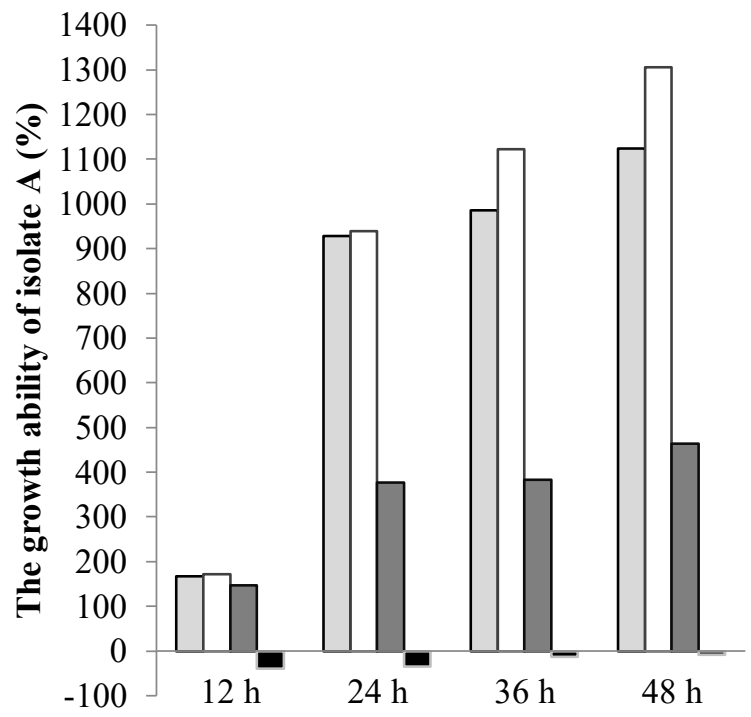

Figure 2. The growth ability of isolate A on MEB medium at at temperature: $20^{\circ} \mathrm{C}(\square), 30^{\circ} \mathrm{C}(\square), 40^{\circ} \mathrm{C}(\square)$ and $50^{\circ} \mathrm{C}(\square)$.

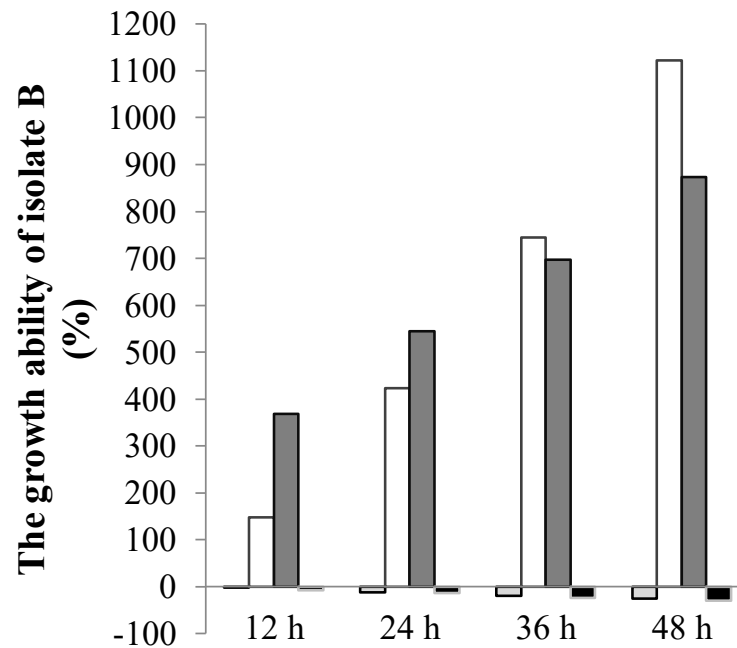

Figure 3. The growth ability of of yeast isolate $\mathrm{B}$ on $\mathrm{MEB}$ medium at temperature: $20^{\circ} \mathrm{C}(\square), 30^{\circ} \mathrm{C}(\square), 40^{\circ} \mathrm{C}(\square)$ and $50^{\circ} \mathrm{C}$

The yeasts isolates A and $\mathrm{B}$ able to growth at $\mathrm{pH} \mathrm{3,4,5,6}$ (Figure 4 and Figure 5). Both isolates had the optimum growth $\mathrm{pH}$ i.e $\mathrm{pH}$ 5. Prescott and Dunn [7] reported that the yeast growth $\mathrm{pH}$ was between 3.0 to 6.0 . 


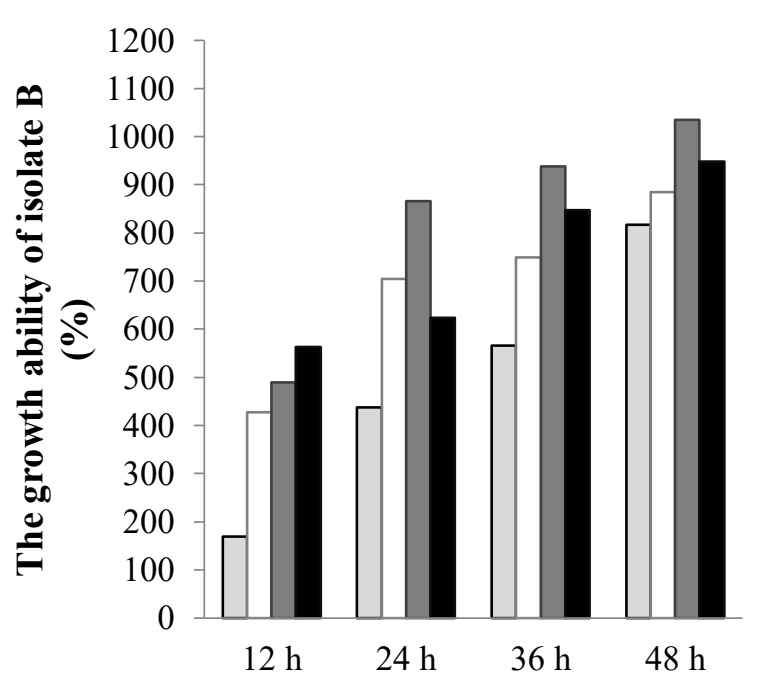

Figure 4. The growth ability of of yeast isolate A on MEB

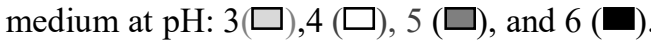

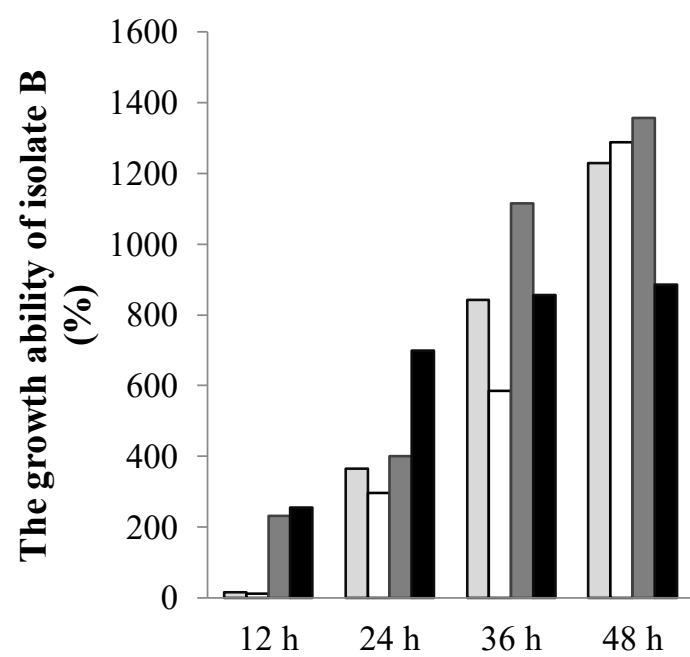

Figure 5. The growth ability of of yeast isolate $\mathrm{B}$ on MEB medium at $\mathrm{pH}: 3^{\circ} \mathrm{C}(\square), 4^{\circ} \mathrm{C}(\square), 40^{\circ} \mathrm{C}(\square)$ and $50^{\circ} \mathrm{C}(\boldsymbol{\square})$.

The isolate $\mathrm{A}$ and isolate $\mathrm{B}$ were able to grow on molasses brix $14^{\circ}, 24^{\circ}$ and $34^{\circ}$. The highest yeast population were at $34^{\circ}$ brix molasses i.e $6.91 \mathrm{Logs} \mathrm{CFU} / \mathrm{ml}$ for isolate A at $48 \mathrm{~h}$ incubation and $6.27 \mathrm{Logs} \mathrm{CFU} / \mathrm{ml}$ for isolate $\mathrm{B}$ at $24 \mathrm{~h}$ incubation. The yeast population at $24^{\circ}$ molasses brix were $6.24 \log \mathrm{CFU} / \mathrm{ml}$ for isolate $\mathrm{A}$ at $48 \mathrm{~h}$ incubation and $6.23 \mathrm{log}$ $\mathrm{CFU} / \mathrm{ml}$ for isolate $\mathrm{B}$ at $24 \mathrm{~h}$ incubation. The yeast population at $14^{\circ}$ molasses brix were $6.86 \log \mathrm{CFU} / \mathrm{ml}$ for isolate $\mathrm{A}$ at $48 \mathrm{~h}$ incubation and $6.20 \log \mathrm{CFU} / \mathrm{ml}$ for isolate $\mathrm{B}$ at $24 \mathrm{~h}$ incubation. Isolates A and $\mathrm{B}$ the highest growth at $34^{\circ}$ brix molasses, because it has the highest sugar concentration than molasses brix $14^{\circ}$ and $24^{\circ}$. It indicated that the isolate $\mathrm{A}$ and B were osmophilic yeast.

Isolates $\mathrm{A}$ increased the highest growth at 48-hour incubation. That was in accordance with the fermentation time needed for fermentation is 2-3 days. Isolates B increased the highest growth at 24-hour incubation. After 20 hours, it was optimum use of sugar by yeast to produce the primary metabolite (ethanol). The ability to grow isolates A and B on molasses brix $14^{\circ}, 24^{\circ}$ and $34^{\circ}$ can be reached $6,17 \log$
$\mathrm{CFU} / \mathrm{ml}$ (0 hours), resulting in an increase to the highest growth (3.15\%) for isolate A and (1.60\%) for isolate B (Figure 6 and Figure 7).

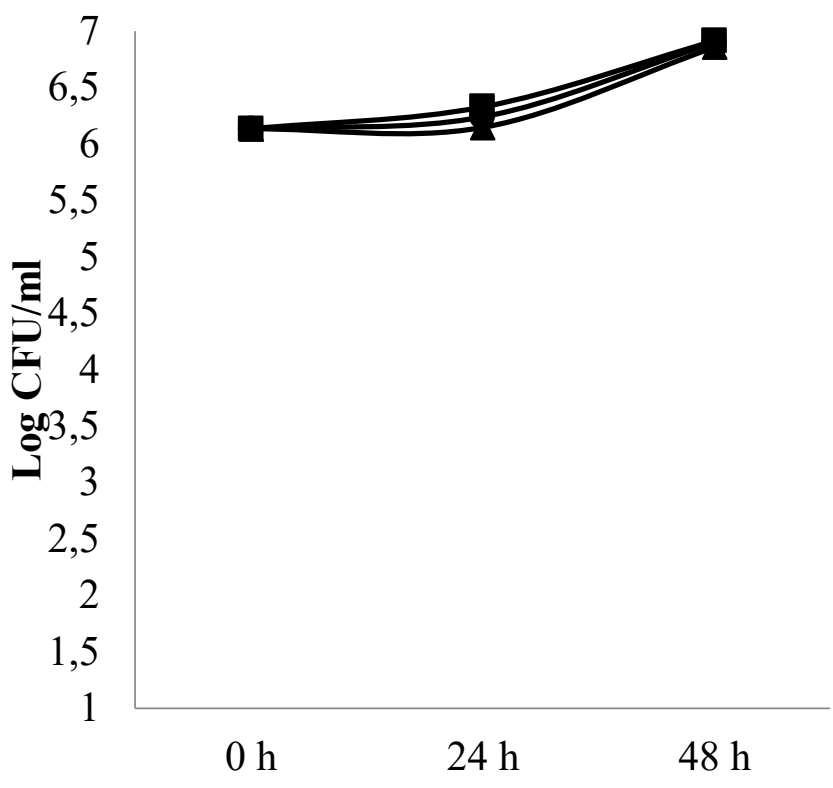

Figure 6. The growth ability of isolate A media molasses brix: $14^{\circ}(\boldsymbol{\Delta}), 24^{\circ}(\bullet), 34^{\circ}(\boldsymbol{\bullet})$ for $24 \mathrm{~h}$ and $48 \mathrm{~h}$ incubation

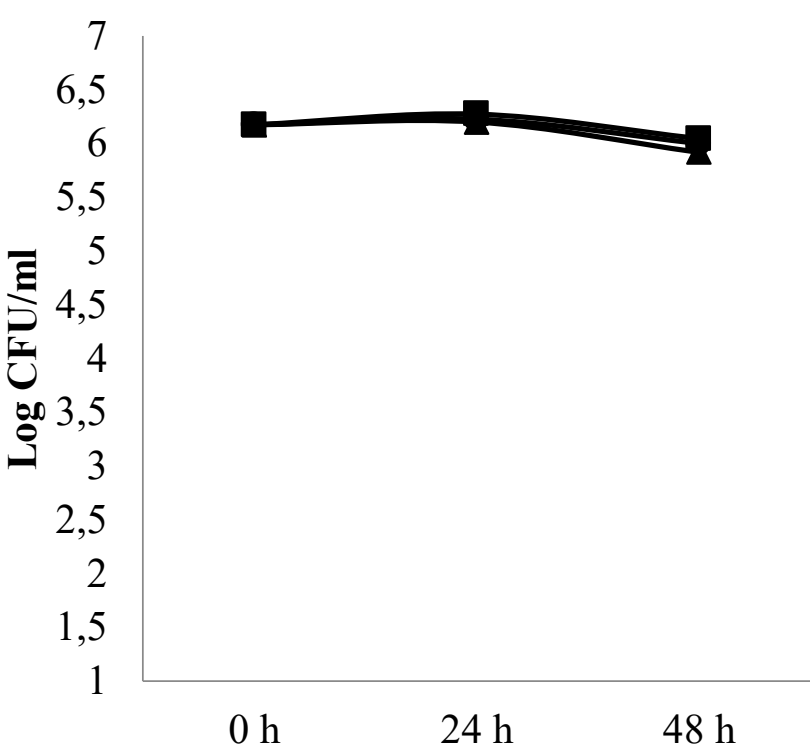

Figure 7. The growth ability of isolate B media molasses brix: $14^{\circ}(\boldsymbol{\Delta}), 24^{\circ}(\bullet), 34^{\circ}(\boldsymbol{\bullet})$ for $24 \mathrm{~h}$ and $48 \mathrm{~h}$ incubation

Evaluation of yeast profile fermentation were determined by incubate the isolates at $20 \mathrm{C}$ Aux API kit for 72 hours. A and $\mathrm{B}$ isolates were grown on 18 kinds of media on the strip kit API 20C Aux. Results obtained in the form of negative or positive reactions, indicated by cloudy or absence of media after 72 hours of incubation. A positive reaction, if the isolates were inoculated make media becomes cloudy, it means that isolates $\mathrm{A}$ or $\mathrm{B}$ can ferment the carbon source in the kit 
substrate and the negative reactions if the kit substrate was clear which means the yeast isolate was not able to ferment the kit substrate. The result showed that isolates A can ferment some sugars such as GLU, Gly, 2KG, ARA, ADO, GAL, INO, SOR, MDG, NAG, CEL, MAL, SAC, TRE, MLZ, RAF on Aux kit API $20 \mathrm{C}$, so that the reaction is positive (+). Isolates A can not ferment kind sugar kind XYL, XLT and LAC on the kit API 20C Aux, and have no hyphae or pseudohyphae, so that the reaction is negative (-). The results were as shown in Table 2.

Results of a positive or negative reaction of the isolates A, was determined to be 7 biocode i.e 63557373 after incubation for 72 hours. The code was a code to identify isolate A. Code 6357373 confirmed on programe web to determine the species of osmophilic yeast. The identification result sreported that isolate A was Candida famata (with identify confidence $63.2 \%$ ). According Dmytruk and Sibirny [8], carbon assimilation test for C. famata that was positive assimilate glucose, galactose, maltose, sucrose, trehalose, Dxylose, melezitose, glycerol, raffinose, Cellobiose, Larabinose; possibility assimilate lactose, starch dissolved, Lrhamnose, D-arabinose; cannot assimilate potassium nitrate and inositol. According Santra [9], C. famata isolated from palm wine beverage, characterization morphological and biochemical tests. The results obtained by the Candida famata can assimilate D-glucose, D-galactose, D-xylose, sucrose, maltose, $\alpha, \alpha$ Trehalose, Cellobiose, lactose, raffinose, and Glycerol; while unable to assimilate Myo-inositol, 2-Keto-Dglucose, starch and L-ramnose. Isolates A has some similarities with the characteristic C. famata above, which was able to assimilate D-glucose, D-galactose, maltose, sucrose, trehalose, melezitose, glycerol, raffinose, Cellobiose, Larabinose, and did not have the pseudohyphae or pseudomycellium. The isolate A have the characteristics of some differences with C. famata above, isolates still incapable of assimilating inostitol and unable to assimilate D-xylose and lactose; while C. famataa can assimilate D-xylose and lactose; and can not assimilate inositol.

The isolate A was doubtful profile so isolate A still needed to be further identified by molecular identification. Conventional identification based on morphological, physiological and biochemical, can lead to misidentification especially in closely related species [10]. The isolate A were identified only $63.2 \%$, which still requires the identification of more accurate, and require the identification of yeast easily, quickly and accurately the method of molecular identification.

Table 3 showed that isolate B can ferment several types of sugars, such as GLU, Gly, 2KG, ARA, XYL, ADO, XLT, GAL, SOR, MDG, NAG, CEL, MAL, SAC, TRE, RAF the kit API 20C Aux, so that the reaction is positive $(+)$. Isolates B can not ferment sugars, such as INO and LAC on the kit API 20C Aux and have no hyphae or pseudohyphaeso that the reaction was negative (-).
Table 2. The fermentation profile of isolates A in Auxkit API $20 \mathrm{C}$

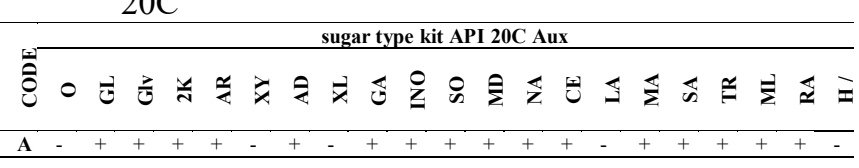

Table 3. The fermentation profile of isolates B in Auxkit API $20 \mathrm{C}$ kit API 20C sugar type Aux

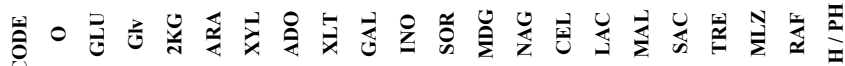

B

Results of positive or negative reaction from isolates B, was determined to be 7 biocode ie 6776373 after incubation for 72 hours. The results showed that isolate B was Candida guilliermondii (84.3\%) with identifying information excelent identificaton to the genus. According to Ogba et al [11] species characterization Candida was performed using kit identification Candida microexpres a test for the assimilation and fermentation of sugar. One of the species Candida that characterized that C. guilliermondii can ferment melibose, sucrose, galactose, cellibiose, xylose, raffinosa and dulcitol, but cannot utilize sugars such as lactose, maltose and inositol. Isolate B had some similarities with the characteristics of C. guilliermondii above, which was able to assimilate sucrose, galactose, cellibiose, xylose, raffinosa and cannot assimilate lactose, inositol. Isolate $\mathrm{B}$ had differences with $C$. guilliermondii that assimilate maltose whereas the isolate $\mathrm{B}$ cannot assimilate maltose. Conventional identification based on morphological, physiological and biochemical, can lead to misidentification especially in closely related species $[11,12]$.

\section{CONCLUSION}

There were obtained two osmophilic yeast isolated from sugarcane molasses. Morphological characteristics of isolate $\mathrm{A}$ and $\mathrm{B}$ were round colonies, colony color white and rounded cell shape and type of multilateral budding; while isolate B had cylindrical cell shape and type of multilateral budding. Optimal physiological characteristics isolate A grew at $30^{\circ} \mathrm{C}$ and $\mathrm{pH} 5$; had the ability to grow on a substrate molasses brix $14^{\circ}, 24^{\circ}$ and $34^{\circ}$; and able to ferment glucose, glycerol, calcium-2-keto-gluconate, arabinose, adonitol, galactose, inositol, sorbitol, methyl- $\alpha \mathrm{D}$-glukopiranosida, N-acetylglucosamine, cellobiosa, maltose, sucrose, trehalose, melezitose, raffinosa. Isolate $\mathrm{B}$ grew optimally at $30^{\circ} \mathrm{C}$ and $\mathrm{pH} 5$; had the ability to grow on a substrate molasses brix 14 $\circ, 24^{\circ}$ and $34^{\circ}$; and able to ferment glucose, glycerol, calcium-2-keto-gluconate, arabinose, xylose, adanitol, xylitol, galactose,sorbitol, methyl- $\alpha \mathrm{D}$-glukopiranosida,N-acetilglucosamine, cellobio sa, maltose, sucrose, trehalose, raffinosa. Isolate A was identified as Candida famata (63.2\%) and isolate $\mathrm{B}$ was identified as Candida guilliermondii $(84.3 \%)$. 


\section{ACKNOWLEDGMENTS}

The authors are grateful to Ministry of Research, Technology and Higher Education of the Republic of Indonesia for funding this research through PUPT research 2018.

\section{REFERENCES}

[1] Harahap, H. 2003. Scientific Production of Alcohol. USU Library.

[2] Gaur K. 2006. Process for The Production of Ethanol Fermentation Via. Dissertation. Deemed University: Patiala, Punjab, India.

[3] Ridawati., Jenie, BSL, Djuwita, I., Sjamsuridzal, W. 2010. Genetic Diversity of yeasts isolated from Indonesian Osmophilic Foods with High Concentration of Sugar. Microbiology Vol 4 (3): 113-118. ISSN 1978-3477.

[4] Van, DV, H. Rahaoui., De Nus and Hartog, BJ 2003. Tracing and PCR Methods for Detection of yeasts In The FoodChain.In: Boekhout, $\mathrm{T}$ and Robert, V. 2003. yeasts in Food: Beneficial and DetrimentalAspects.CRC Press, Boca Raton: 123-138.

[5] Kurtzman, CP and Sugiyama, J. 2001. Ascomycetous yeasts and Yeastlike Taxa.In: McLaughlin, DJ, McLaughlin, EG and Lemke, PA, 2001. The Mycota VII Part A: Systematics andEvolution.SpringerVerlag, Berlin: 179-200.

[6] Fardiaz, S. 1992. Food Microbiology I. Jakarta: Gramedia Pustaka Utama. (Indoneseian)

[7] Prescott, SC and Dunn, G. 1981. Industrial Microbiology. Mc Graw Hill Book Co. Ltd., New York.

[8] Dmytruk, KV and Sibirny, A. A. 2012. famata Candida (Candida flareri). Yeast 29: 453-458. Wiley Online Library.DOI: 10.1002 / yea. 2929

[9] Santra, T., Ghosh, S. K and Chakravarty, A. 2014. Different Methods for DNA Extraction from Yeast-Candida famata Isolated from Toddy. British Biotechnology Journal 4 (1): 64-73.

[10] Fell, JW, Boekhout, T., Fonseca, A., Scorzetti, G and Statzell, TA 2000. Biodiversity and Systematic of Basidiomycetous yeasts as Determined by Large subunit rDNA-D1 / D2 domain SequnceAnalysiss. Journal of System Evolution Microbiol 50: 1351-1371.

[11] Ogba, OM, Abia-Bassey, LN, Epoke, J., Foreman, BI, Iwatt, GD 2013. The characterization of Candida Species Isolated from Cases of Lower Respiratory Tract Infection among HIV / AIDS Patients in Calabar, Nigeria. World Journal of AIDS 3: 201-206

[12] Roostita, R. 1993. Occurrence, Growth and Biochemical Properties of yeasts in Cheeses and Milk. Thesis. The University of New South Wales, Australia. 